\title{
ENKRIPSI DAN DEKRIPSI CITRA MENGGUNAKAN METODE FRAKTAL
}

\author{
Janoe Hendarto \\ Departemen Ilmu Komputer dan Elektronika \\ Fakultas Matematika dan Ilmu Pengetahuan Alam \\ Universitas Gadjah Mada \\ email :jhendarto@ugm.ac.id
}

\begin{abstract}
Abstraksi
Enkripsi citra dengan metode fraktal adalah proses penyandian yang mengubah citra asli (plain image) menjadi citra yang tidak bisa dimengerti (cipher image) dengan menggunakan citra fraktal (fraktal image). Sedangkan dekripsi citra adalah proses sebaliknya yaitu mengubah cipher image menjadi citra asli. Citra fraktal yang digunakan pada penelitian ini adalah citra himpunan Mandelbrot $z^{2}-c$ pada domain tertentu, dengan z adalah variabel komplek.

Pertama, dibahas bagaimana enkripsi dan dekripsi citra warna menggunakan citra himpunan Mandelbrot dengan data domainnya dijadikan sebagai kunci(key). Proses enkripsi dilakukan dengan merubah setiap pixel dari citra asli yaitu merubah nilai bit ke-2 (0 menjadi 1 atau 1 menjadi 0) kemudian ditambahkan nilai warna dari citra fraktalnya sehingga diperoleh citra terenkrip. Sedangkan proses dekripsi adalah proses sebaliknya, yaitu setiap pixel dari citra terenkrip nilai warnanya dikurangi nilai warna dari citra fraktalnya kemudian dirubah nilai bit ke-2nya (0 menjadi 1 atau 1 menjadi 0) sehingga diperoleh citra hasil dekripsi yang diharapkan sama dengan citra asli. Kemudian, dibuat program komputer yang mampu melakukan enkripsi dan dekripsi citra warna menggunakan citra himpunan Mandelbrot, baik yang single fractal maupun multi fractal, dan selanjutnya dilakukan analisis terhadap hasil program. Citra hasil enkripsi dari 6 citra uji dianalisis dengan menentukan nilai NPCR dan UACI, dimana nilai NPCR semuanya 100\% sedangkan rerata nilai UACI adalah 31,47\%. Waktu enkripsi reratanya adalah 2.95 detik dan waktu dekripsi reratanya 2,89 detik. Citra hasil dekripsi mempunyai $R M S E=0$ terhadap citra asli, hal ini menunjukkan bahwa citra hasil dekripsi sama persis dengan citra asli, sedangkan dari hasil nilai UACI dari beberapa data uji dan juga berdasarkan pengamatan secara visual didapat bahwa citra hasil enkripsi menggunakan multi fraktal sedikit lebih baik dibandingkan dengan single fraktal.
\end{abstract}

\section{Kata kunci: Enkripsi, Dekripsi, Himpunan Mandelbrot, Citra fraktal.}

\begin{abstract}
Fractal image encryption is an encoding process that converts the plain image into a cipher image by using a fractal image, while fractal image decryption is the reverse process, that changing the cipher image into the original image. The fractal image used in this research is the Mandelbrot set image of $z^{2}-c$ in a particular domain, where $z$ is a complex variable.

First, it discusses how to encrypt and decrypt color images using the image of the Mandelbrot set with using the domain as a key. The encryption process is carried out by changing each pixel of the plain image, that is changing the bit value of the 2 nd bit (0 to 1 or 1 to 0$)$ then adding the color value of the fractal image to obtain an encrypted image. While the decryption process is the reverse process, ie each pixel of the encrypted image its color value minus the color value of the fractal image then the 2nd bit value is changed ( 0 to 1 or 1 to 0 ) so that the decrypted image is the same as the original image. Then, a computer program was created that was able to encrypt and decrypt color images using Mandelbrot set images, both single fractal and multi fractal, and then analyzed the results of the program. The encrypted images from 6 test images were analyzed by determining the NPCR and UACI values, where the NPCR values were all 100\% while the average UACI value was $31.47 \%$. The average encryption time is 2.95 seconds and the average decryption time is 2.89 seconds. The decrypted image has RMSE $=0$ to the original image, this shows that the decrypted image is exactly the same as the plain image and from the UACI value of some test data and also based on visual observations show that the encrypted image using multi fractals is slightly better compared to a single fractal.
\end{abstract}

Keywords: Encryption, Decryption, Mandelbrot Set, Fractal Image. 


\section{Pendahuluan}

Kriptografi merupakan cara pengamanan data yang telah dikenal sejak dahulu, memiliki dua proses yaitu enkripsi dan dekripsi. Enkripsi citra dengan metode fraktal adalah proses penyandian yang mengubah citra asli (plain image) menjadi citra yang tidak bisa dimengerti (cipher image) dengan menggunakan citra fraktal (fraktal image). Sedangkan dekripsi citra adalah proses sebaliknya yaitu mengubah cipher image menjadi citra asli. Citra fraktal yang digunakan pada penelitian ini adalah citra Mandelbrot $\mathrm{z}^{2}-\mathrm{c}$ pada domain tertentu, dengan $\mathrm{z}$ adalah variabel komplek.

Algoritma kriptografi konvensional seperti DES, IDEA dan yang lainnya sebagian dianggap kurang cocok dalam pengamanan informasi citra. Karena data citra memiliki volume data besar, redudansi tinggi dan pixel saling berhubungan. Proses enkripsi seharusnya membuat pixel di dalam citra tidak lagi berhubungan sehingga menyulitkan penyerang dalam melakukan analisis statistik. Enkripsi citra menggunakan metode fraktal dipilih karena dianggap cocok untuk mengenkripsi citra karena sifat fraktal yang kaotik dan citra fraktal dapat dikodekan sehingga diharapkan menyulitkan penyadap dalam mengenali citra tersebut.

Pada penelitian ini dielaborasi dan dikaji (a). Bagaimana melakukan enkripsi dan dekripsi sebuah citra menggunakan citra fraktal. (b). Bagaimana efisiensi dari metode enkripsi dan dekripsi sebuah citra menggunakan citra fraktal dan bagaimana kualitas dari citra hasil enkripsi dan dekripsi. c). Bagaimana program komputer untuk melakukan enkripsi dan dekripsi sebuah citra menggunakan citra fraktal.

Hasil tinjauan pustaka tentang enkripsi dan dekripsi menggunakan metode fraktal dapat dilihat pada Tabel 1.

\begin{tabular}{|c|c|c|}
\hline Peneliti & Topik Penelitian, Metode yang digunakan & Kekurangan/kelemahan \\
\hline Lock dkk.,2010 & $\begin{array}{l}\text { Mengenalkan ide baru menggabungkan kompresi } \\
\text { dan enkripsi dengan menggunakan geometri fraktal, } \\
\text { yaitu dengan mengkonversi himpunan Mandelbrot } \\
\text { dan gambar terkompresi menjadi matriks persegi. } \\
\text { Gambar dikompresi dengan menggunakan Sistem } \\
\text { Fungsi Iterasi, kemudian, operasi matriks } \\
\text { diterapkan untuk mengenkripsi citra. }\end{array}$ & $\begin{array}{l}\text { Menggunakan } 1 \text { citra } \\
\text { himpunan Mandelbrot, } \\
\text { belum citra multi fraktal } \\
\text { dan belum menganalisis } \\
\text { citra hasil enkripsi dengan } \\
\text { parameter NPCR dan } \\
\text { UACI. }\end{array}$ \\
\hline Sun dkk., 2010 & $\begin{array}{l}\text { menggunakan kombinasi Himpunan Mandelbrot } \\
\text { dan transformasi Hilbert untuk menghasilkan kunci } \\
\text { acak yang diharapkan bisa mengurangi ruang } \\
\text { penyimpanan karena himpunan Mandelbrot } \\
\text { diiterasi hanya dengan beberapa parameter. }\end{array}$ & $\begin{array}{l}\text { Belum menggunakan citra } \\
\text { multi fraktal dan belum } \\
\text { menganalisis citra hasil } \\
\text { enkripsi dengan parameter } \\
\text { NPCR dan UACI. }\end{array}$ \\
\hline $\begin{array}{l}\text { Abd-El-Hafiz } \\
\text { dkk., } 2014\end{array}$ & $\begin{array}{l}\text { Memperkenalkan sistem enkripsi citra berdasarkan } \\
\text { proses difusi dan konfusi di mana informasi citra } \\
\text { disembunyikan di dalam detail citra fraktal yang } \\
\text { kompleks. Dimulai dengan teknik enkripsi citra } \\
\text { yang sederhana yaitu menggunakan satu citra } \\
\text { fraktal hingga menggunakan } 7 \text { citra fraktal agar } \\
\text { diperoleh metode enkripsi yang handal, akan tetapi } \\
\text { ukuran kunci enkripsi menjadi membesar. }\end{array}$ & $\begin{array}{l}\text { Ukuran kunci enkripsi } \\
\text { masih relatif besar. }\end{array}$ \\
\hline $\begin{array}{l}\text { Chopra dkk., } \\
2015\end{array}$ & $\begin{array}{l}\text { Mengusulkan skema enkripsi yang disempurnakan } \\
\text { dari enkripsi citra berbasis modulo yang disarankan } \\
\text { oleh Rozouvan dkk. yaitu menggunakan citra } \\
\text { fraktal untuk menghasilkan kunci yang handal } \\
\text { untuk enkripsi citra, dengan menggabungkan teori } \\
\text { chaos bersama dengan penggunaan kunci fraktal. }\end{array}$ & $\begin{array}{l}\text { Menggunakan citra metode } \\
\text { iterasi Newton dan belum } \\
\text { menggunakan citra multi } \\
\text { fraktal. }\end{array}$ \\
\hline $\begin{array}{l}\text { Lan dan } \mathrm{Wu}, \\
2018\end{array}$ & $\begin{array}{l}\text { Mengusulkan skema enkripsi citra berdasarkan } \\
\text { invers fungsi interpolasi fraktal yang mempunyai } \\
\text { sifat chaos yang sempurna sehingga menghasilkan } \\
\text { deret pseudo-random untuk mengacak posisi piksel }\end{array}$ & $\begin{array}{l}\text { Menggunakan interpolasi } \\
\text { fraktal, belum } \\
\text { menggunakan citra fraktal. }\end{array}$ \\
\hline
\end{tabular}




\begin{tabular}{|c|c|c|}
\hline & $\begin{array}{l}\text { citra asli dan kemudian melakukan difusi citra yang } \\
\text { diacak untuk mendapatkan citra terenkrip. }\end{array}$ & \\
\hline $\begin{array}{l}\text { Zhang dkk., } \\
2019\end{array}$ & $\begin{array}{l}\text { Menggusulkan teknik enkripsi citra baru yaitu } \\
\text { berdasarkan sifat pengisian ruang kurva Hilbert } \\
\text { dan sifat tak hingga dari fraktal geometris-H, yang } \\
\text { menggabungkan pseudorandomness dari sistem } \\
\text { hyperchaotic dan sensitivitas terhadap nilai awal. }\end{array}$ & $\begin{array}{l}\text { Citra yang dienkrip } \\
\text { merupakan citra grayscale } \\
\text { dan belum menggunakan } \\
\text { citra fraktal. }\end{array}$ \\
\hline $\begin{array}{l}\text { Gupta dan Vijay, } \\
2020\end{array}$ & $\begin{array}{l}\text { Menggunakan teknik enkripsi simetris AES dan } \\
\text { DES terhadap citra yang dikompresi dengan metode } \\
\text { fraktal, sehingga diharapkan ukuran citra menjadi } \\
\text { lebih kecil. }\end{array}$ & $\begin{array}{l}\text { Citra yang dienkrip } \\
\text { merupakan citra grayscale } \\
\text { dan belum menggunakan } \\
\text { citra fraktal. }\end{array}$ \\
\hline
\end{tabular}

Tabel 1 Tabel Hasil Tinjauan Pustaka

Dari penelitian-penelitian di atas, sebagian besar membahas enkripsi citra menggunakan metode fraktal dengan memanfaatkan sifat kaotiknya, belum banyak yang menggunakan citra fraktal untuk melakukan enkripsi suatu citra warna, Penelitian yang ada hanya menggunakan satu macam citra fraktal dan masih perlu ditingkatkan ukuran memory kuncinya agar bisa lebih kecil lagi. Pada penelitian ini dibahas metode enkripsi dan dekripsi citra warna menggunakan citra fraktal yaitu citra Mandelbrot dan akan dicari kunci yang lebih efisien tapi tetap handal dan tahan terhadap serangan.

\section{Metode Penelitian}

Langkah-langkah yang dilakukan dalam penelitian ini adalah:

1. Studi pustaka, mulai dari referensi buku hingga mempelajari paper-paper mengenai enkripsi secara umum dan enkripsi citra dengan metode fraktal.

2. Analisis permasalahan dan analisis terhadap metode/algoritme enkripsi dan dekripsi citra dengan menggunakan metode fraktal, terutama permasalahan enkripsi dan dekripsi citra dengan citra fraktal.

3. Perancangan aplikasi enkripsi dan dekripsi citra menggunakan citra fraktal yaitu citra himpunan Mandelbrot, secara garis besar langkah-langkah enkripsi dan dekripsi citra menggunakan citra fraktal dapat dinyatakan dengan diagram alir pada Gambar 1.

4. Mengimplementasikan aplikasi dalam bentuk program, dengan menggunakan bahasa pemrograman Delphi.

5. Menguji kebenaran program dan menganalisis hasil program (efisiensi algoritme dan mengukur kualitas dan keamanan citra hasil) dari aplikasi enkripsi dan dekripsi citra menggunakan citra fraktal.

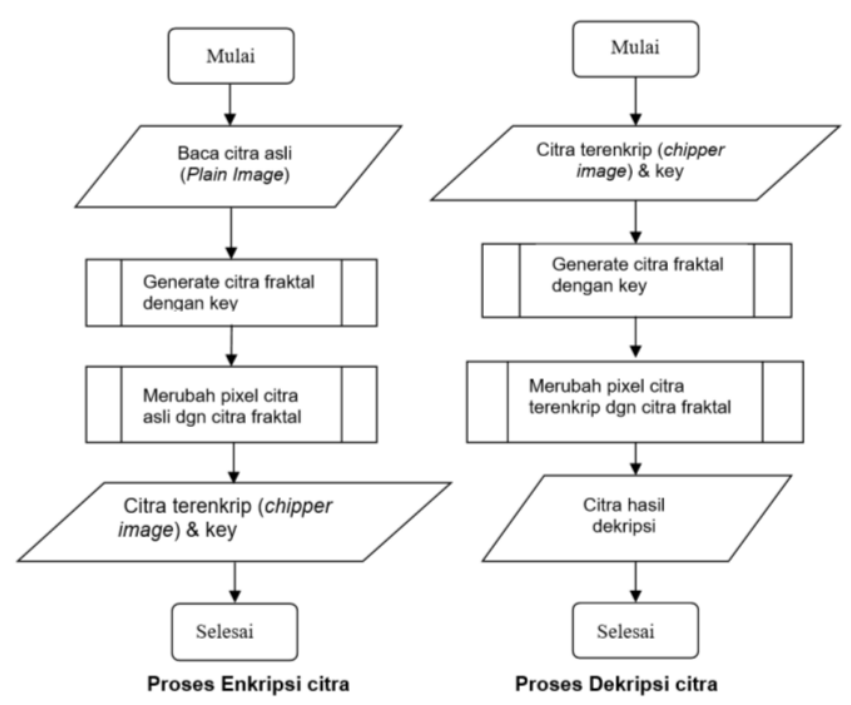

Gambar 1. Diagram alir enkripsi dan dekripsi citra dengan citra fraktal 


\section{Hasil dan Pembahasan}

Penelitian ini dilakukan pertama menyiapkan citra fraktal (fraktal image) yang berupa gambar himpunan Mandelbrot yang akan digunakan sebagai citra kunci, kemudian menyiapkan data uji beberapa citra warna (plain image) yang akan dienkrip, kemudian dirancang algoritme dan program komputer untuk melakukan enkripsi dan dekripsi citra warna dengan metode fraktal dan akhirnya dianalisis hasil program komputernya.

\section{A. Penyiapan Citra fraktal dan Citra Uji}

Citra fraktal yang digunakan sebagai citra kunci adalah citra berukuran 512x512 pixel, yaitu gambar himpunan Mandelbrot dari fungsi komplek $\mathrm{z}^{2}-\mathrm{c}$ dengan berbagai daerah domain $\mathrm{z}$ yang dapat dicari melalui proses zooming dari gambar himpunan Mandelbrot dengan domain yaitu $-0.75 \leq \mathrm{x} \leq 2.25$ dan $-1.5 \leq \mathrm{y} \leq 1.5$, kemudian mengenerate citra multi fraktal dengan operasi geseran dan XOR terhadap citra single fraktal, dalam penelitian ini digunakan 5 citra single fraktal Mandelbrot dan 5 citra multi fraktal, selengkapnya dapat dilihat pada Gambar 2. Sedangkan untuk citra uji yang digunakan dalam proses enkripsi dan dekripsi adalah 6 citra warna yaitu citra Lenna (a), citra Barbara (b), citra Pepper(c), citra Baboon(d), citra UGM(e) dan citra Sailboat(f) dengan ukuran 512×512 pixel. selengkapnya dapat dilihat pada Gambar 3.
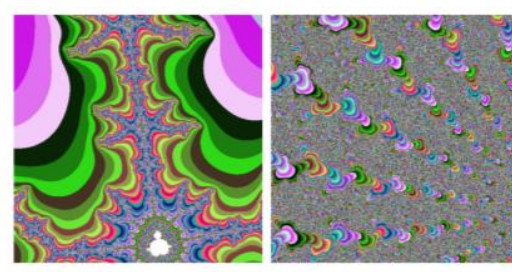

Mandelbrot1

9.99298095703125E-0002 $1.04507446289062 \mathrm{E}-0001$ $9.43725585226537500 \mathrm{E}-0001$

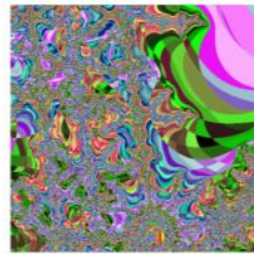

Mandelbrot1

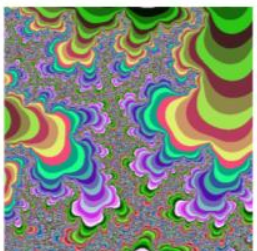

Mandelbrot3

$1.00521888770163 \mathrm{E}+0000$ $1.00522587262094 \mathrm{E}+0000$ $3.10281160287559 \mathrm{E}-0001$

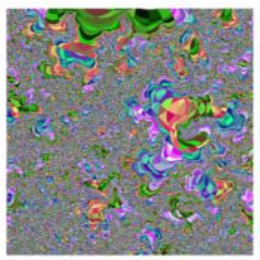

Mandelbrot3

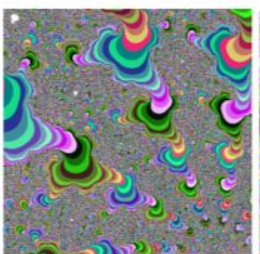

Mandelbrot4 $7.28668212890625 \mathrm{E}-0001$ $-2.41149902343750 \mathrm{E}-0001$ $-2.36572265625000 \mathrm{E}-0001$

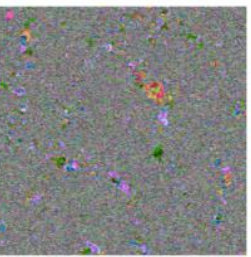

Mandelbrot4

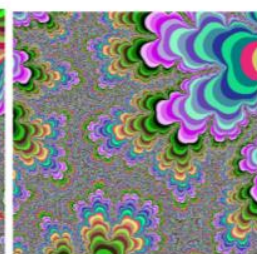

Mandelbrot5

1.39406012815016E+000 1.39406040099857E+0000 $1.53038223506882 \mathrm{E}-0002$ $1.53040951990988 \mathrm{E}-0002$

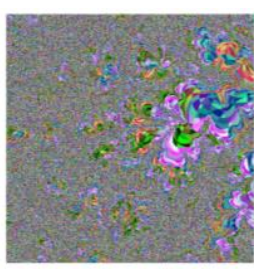

Mandelbrot5

Gambar 2. Citra single fraktal (atas) dan citra multi fraktal ( bawah )

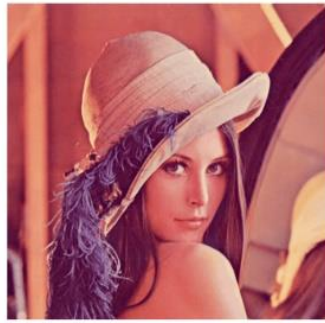

a

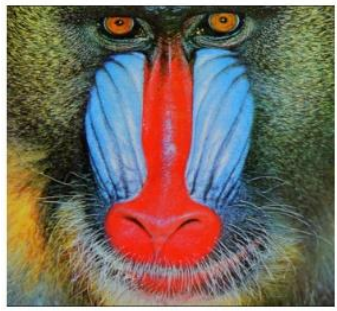

d

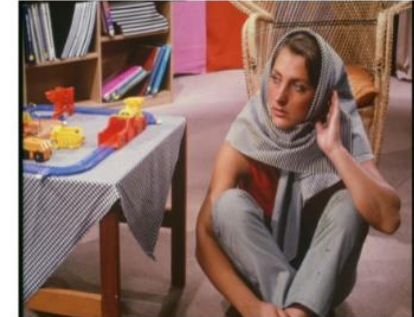

b

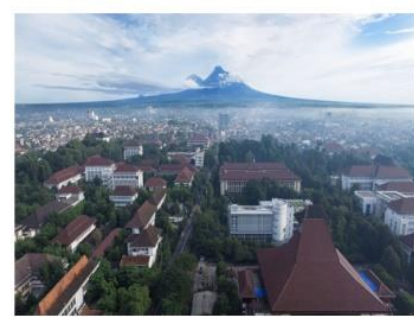

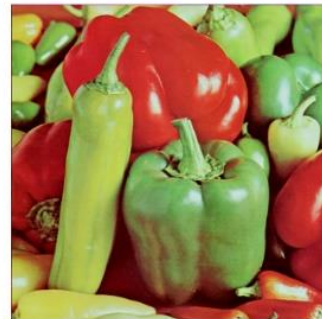

c

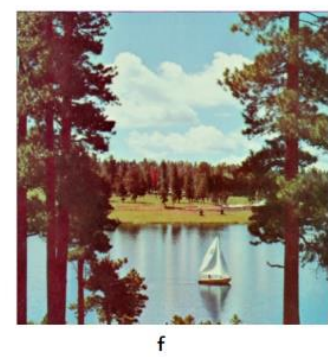

Gambar 3. Beberapa Citra Warna sebagai Citra Uji 


\section{B. Algoritme dan Program Enkripsi dan Dekripsi Citra menggunakan Citra Fraktal.}

Enkripsi citra dengan metode fraktal adalah sebuah proses penyandian yang mengubah citra asli (plain image) menjadi citra yang tidak bisa dimengerti (cipher image) dengan menggunakan citra fraktal (fraktal image). Sedangkan dekripsi citra adalah proses sebaliknya yaitu mengubah cipher image menjadi citra asli. Citra fraktal yang digunakan pada penelitian ini adalah citra Mandelbrot $\mathrm{z}^{2}-\mathrm{c}$ pada domain tertentu, dengan $\mathrm{z}$ adalah variabel komplek.

Proses enkripsi dan dekripsi citra dengan metode fraktal, pertama ditentukan citra fraktal yang digunakan, batas-batas daerah domain dari citra fraktal disimpan dijadikan sebagai kunci. Proses enkripsi dilakukan dengan merubah setiap pixel dari citra asli yaitu merubah nilai bit ke-2 (0 menjadi 1 atau 1 menjadi 0 ) kemudian ditambahkan nilai warna dari citra fraktalnya sehingga diperoleh citra terenkrip. Sedangkan proses dekripsi adalah proses sebaliknya, yaitu setiap pixel dari citra terenkrip nilai warnanya dikurangi nilai warna dari citra fraktalnya kemudian dirubah nilai bit ke-2nya ( 0 menjadi 1 atau 1 menjadi 0 ) sehingga diperoleh citra hasil dekripsi yang diharapkan sama dengan citra asli.

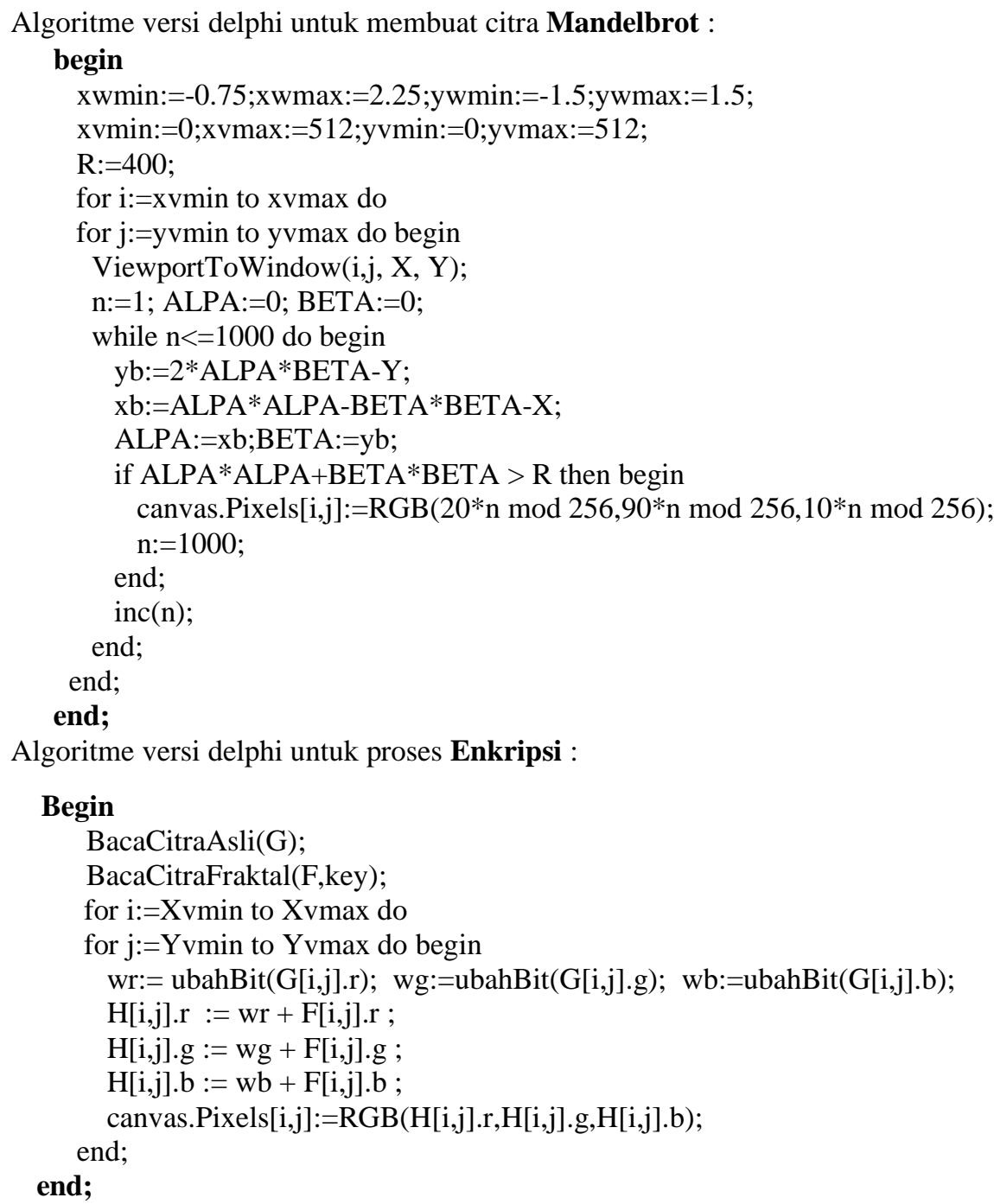

Algoritme versi delphi untuk proses Dekripsi :

\section{Begin}

BacaCitraHasilEnkripsi(H);

BacaCitraFraktal(F,key);

for $\mathrm{i}:=$ Xvmin to Xvmax do 


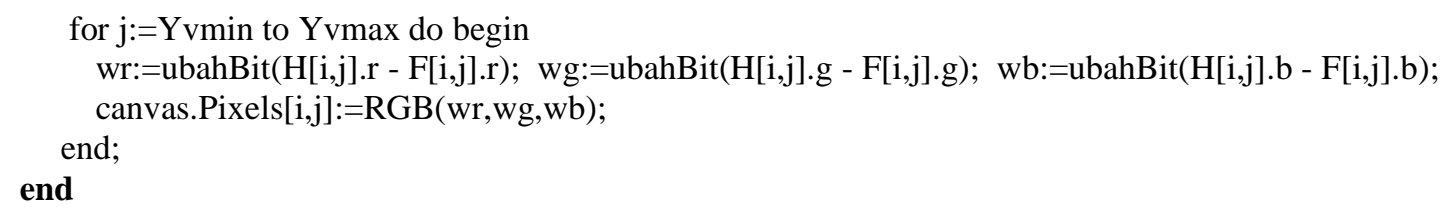

Telah dirancang algoritme dan program komputer untuk melakukan enkripsi dan dekripsi citra menggunakan citra fraktal himpunan Mandelbrot, dimana citra asli dienkripsi menggunakan citra fraktal Mandelbrot yang dipilih, menghasilkan citra terenkrip, kemudian program dapat melakukan dekripsi yang merubah citra terenkrip kembali menjadi citra asli. Program yang dibuat juga menampilkan waktu yang diperlukan untuk melakukan enkripsi dan dekripsi, juga menentukan Number of Pixels Change Rate (NPCR) dan Unifer Average Changing Intensity (UACI) dari citra hasil enkripsi dibandingkan dengan citra asli, serta menampilkan nilai parameter kemiripan antara citra asli dan citra hasil dekripsi yaitu dengan menentukan RMSE (Root Mean Squared Error) dan PSNR (Peak Signal-to-Noise Ratio). Tampilan utama program dapat dilihat pada Gambar 4.

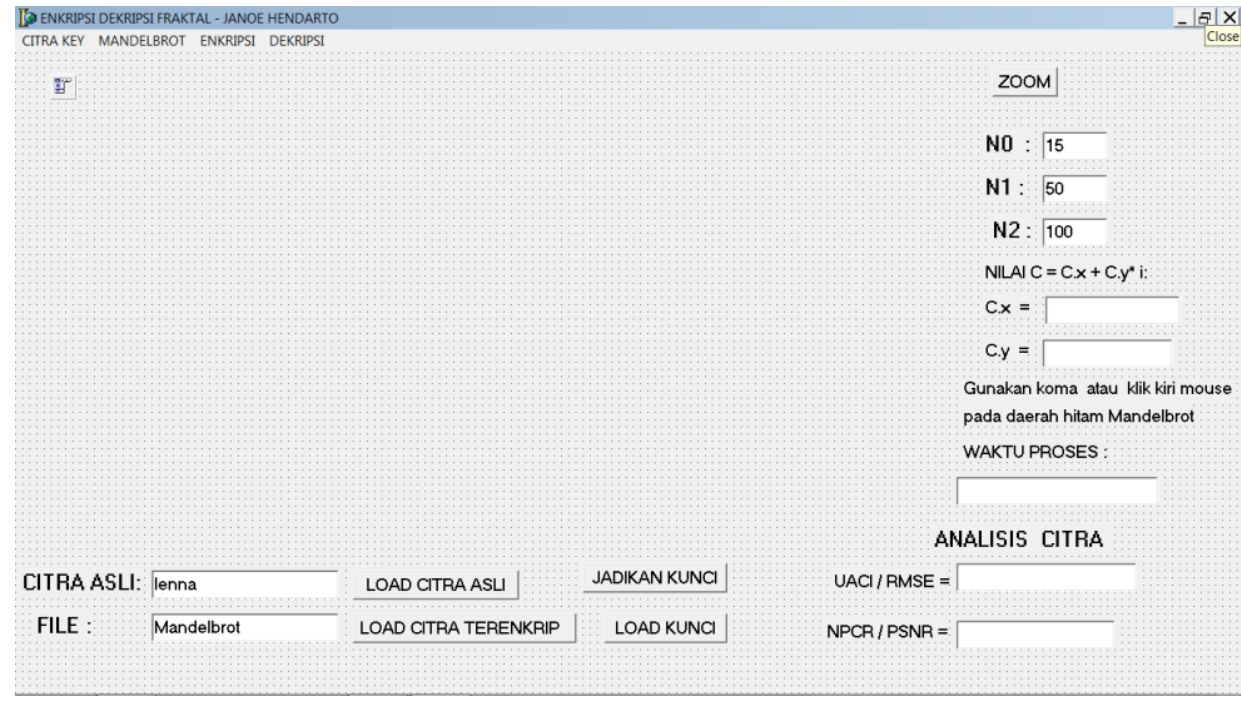

Gambar 4. Tampilan Program Enkripsi dan Dekripsi

Program dapat membuat citra single fraktal maupun multi fraktal kemudian menyimpan key nya dan melakukan enkripsi dan dekripsi terhadap suatu citra asli serta menampilkan hasil analisisnya.

\section{Analisis Hasil Program Enkripsi dan Dekripsi Citra menggunakan Citra Fraktal}

Dalam menganalisis hasil program enkripsi dan dekripsi diperlukan beberapa parameter, yang pertama untuk mengukur kesamaan antara citra asli dengan citra hasil dekripsi diperlukan parameter RMSE dan PSNR , jika RMSE = 0 maka tidak perlu menentukan PSNR karena kedua citra persis sama, rumus RMSE dan PSNR adalah sebagai berikut :

PSNR $=20 . \log _{10}(255 /$ RMSE $) \quad$ (untuk citra RGB)

dengan RMSE adalah $=\sqrt{\frac{\sum_{0 \leq i \leq m-1 ; 0 \leq j \leq n-1}\left(Z_{i, j}-Y_{i, j}\right)^{2}}{m x n}}$ dengan $\mathrm{Z}_{\mathrm{i}, \mathrm{j}}$ nilai warna pixel $(\mathrm{i}, \mathrm{j})$ dari citra hasil dekripsi dan $Y_{i, j}$ nilai warna pixel $(i, j)$ dari citra asli.

$\mathrm{m}$ dan $\mathrm{n}$ adalah ukuran lebar dan tinggi citra $(\mathrm{m}=512, \mathrm{n}=512)$.

Sedangkan untuk menganalisis hasil proses enkripsi, algoritme dalam mengenkripsi citra dari serangan diferensıa. Aaa aua parameter yang serıng aıgunakan dalam menganalisis diferensial, yaitu Number of Pixels Change Rate (NPCR) dan Unifer Average Changing Intensity (UACI). NPCR digunakan untuk menghitung berapa banyak perbedaan pixel dari dua buah citra (persentase), sedangkan UACI berfokus pada interval perbedaan nilai pixel dari kedua citra yaitu 
menghitung persentase perubahan warna terpadu pada citra asli terhadap citra hasil enkripsi. Rumus perhitungan NPCR dan UACI adalah sebagai berikut :

$$
\begin{gathered}
\text { NPCR }=\sum_{i, j} \frac{D(i, j)}{N} \times 100 \% \\
\mathrm{UACI}=\sum_{i, j} \frac{\left|C^{1}(i, j)-C^{2}(i, j)\right|}{(F \cdot N)} \times 100 \% .
\end{gathered}
$$

dengan $\mathrm{D}(\mathrm{i}, \mathrm{j})=0$ jika sama nilai pixelnya atau 1 jika berbeda, $\mathrm{N}$ adalah total banyak pixel yaitu

Program komputer yang dibuat, pertama membaca citra asli, Gambar 5 menunjukkan hasil pembacaan citra uji Barbara, kemudian program dapat membuat atau membaca citra fraktal yang sudah disimpan, Gambar 6 menunjukkan citra multi fraktal Mandelbrot. Kemudian program siap melakukan enkripsi dan dekripsi, hasil enkripsi citra Barbara menngunakan citra multi fraktal Mandelbrot dapat dilihat pada Gambar 7 dimana nilai UACI adalah 30,14\% dan NPCR adalah 100\%. Proses dekripsi dapat dilakukan berdasarkan data enkripsi atau membaca citra hasil enkripsi, contah hasil dekripsi dapat dilihat pada Gambar 8 dimana nilai RMSE adalah 0 artinya citra hasil dekripsi sama persis dengan citra aslinya dan secara visual juga citra hasil dekripsi terlihat sama dengan citra asli. Hasil enkripsi beberapa citra uji menggunakan citra multi fraktal yang berbeda yaitu multi fraktal Mandelbrot 2 dapat dilihat pada Gambar 9, terlihat bahwa secara visual ke empat citra hasil enkripsi sangat mirip padahal dari citra uji yang berbeda beda.

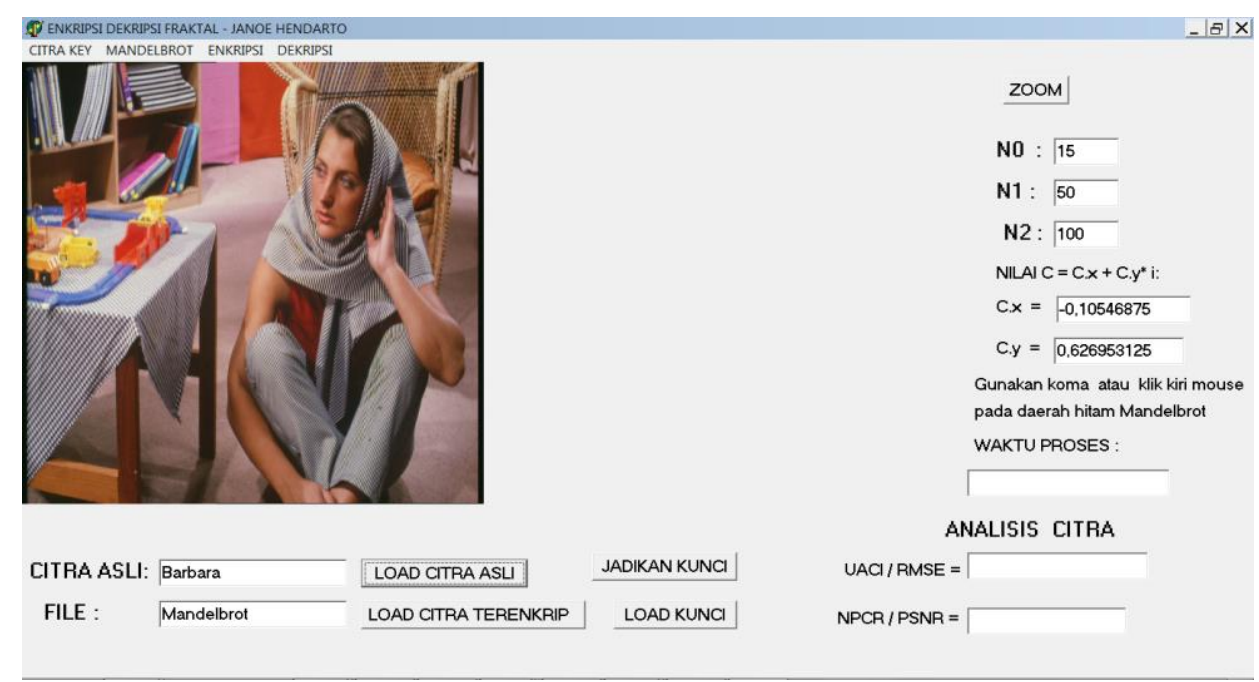

Gambar 5. Hasil Program Pembacaan Citra Uji Barbara

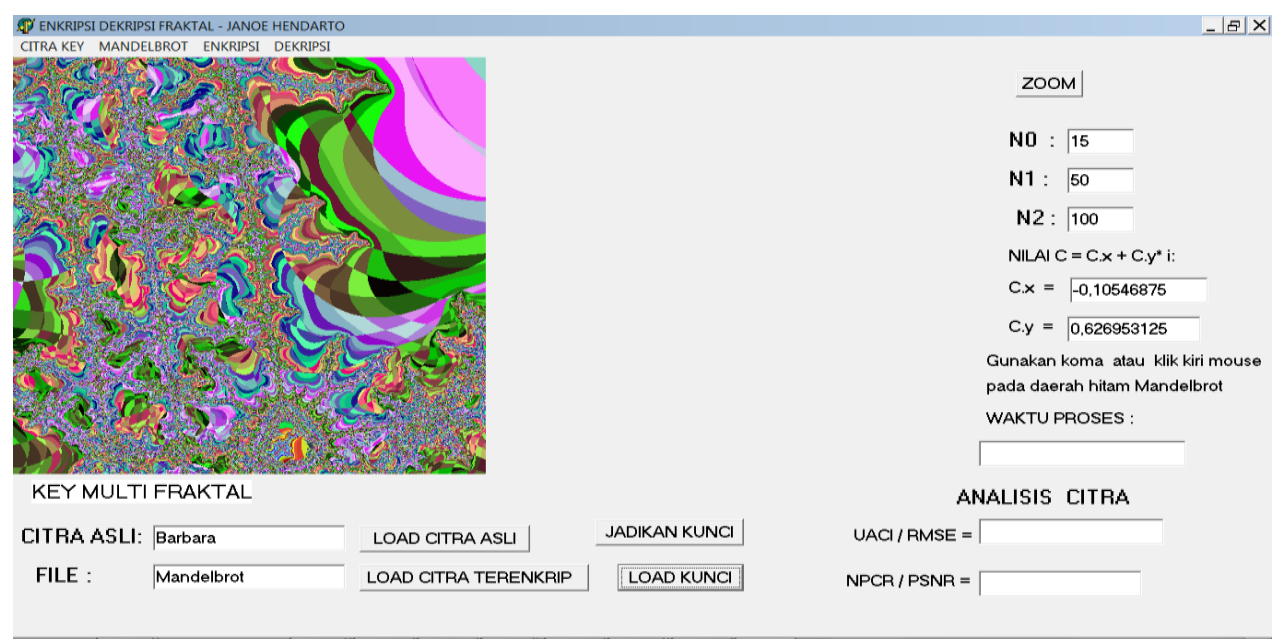

Gambar 6. Hasil Program Pembacaan Citra Multi Fraktal Mandelbrot 


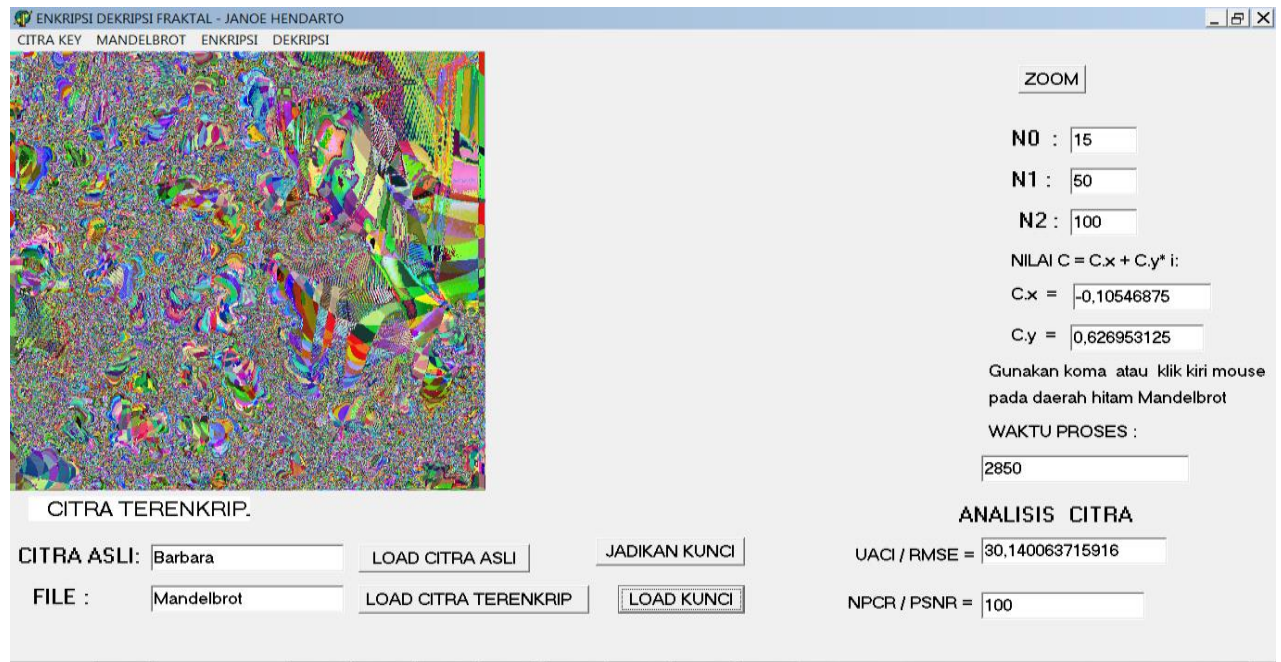

Gambar 7. Hasil Program Proses Enkripsi Citra Barbara

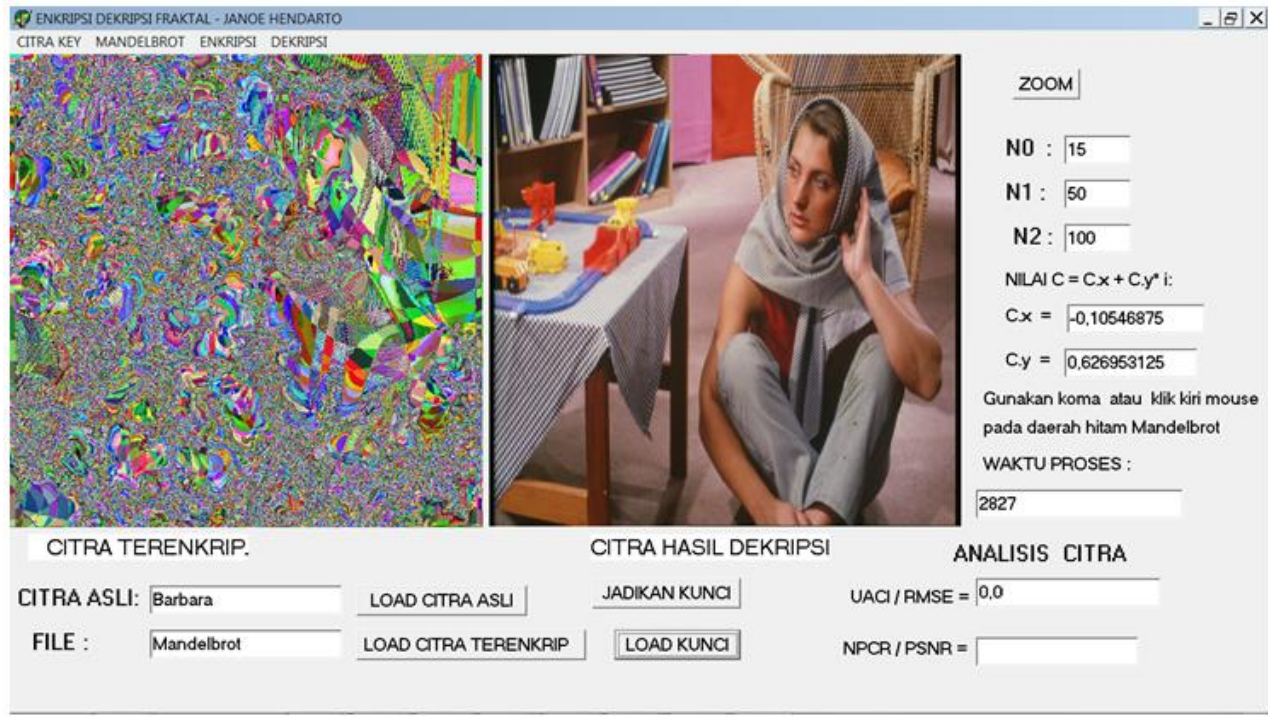

Gambar 8. Hasil Program Proses Dekripsi Citra Barbara
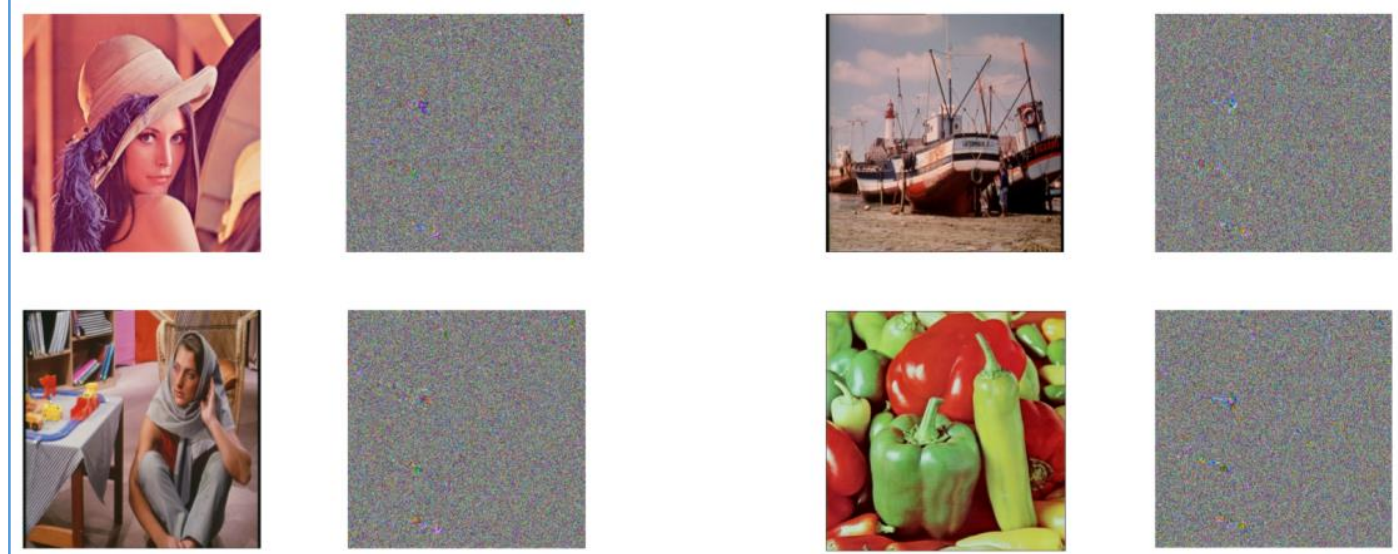

Gambar 9. Hasil Enkripsi dari 4 Citra Uji

Dari beberapa hasil uji proses enkripsi dan dekripsi dengan menggunakan 6 citra uji dan menggunakan citra multi fraktal Mandelbrot3 didapat hasil seperti pada Tabel 3. Dari table tersebut didapat nilai UACI mempunyai rerata $31,47 \%$, waktu yang diperlukan untuk proses enkripsi rerata 2.95 detik dan waktu yang 
diperlukan untuk proses dekripsi rerata 2,89 detik, Sedangkan untuk nilai NPCR semuanya 100\%. Kemudian juga dilakukan uji enkripsi menggunakan citra fraktal single dan multi untuk 3 macam citra uji, hasilnya dapat dilihat pada Tabel 3, dari table tersebut terlihat citra hasil enkripsi menggunakan citra multi fraktal sedikit lebih baik dibandingkan menggunakan citra single fraktal. Untuk analisis hasil proses dekripsi, diperoleh bahwa semua citra hasil dekripsi mempunyai nilai RMSE $=0$ terhadap citra asli, hal ini juga dibenarkan jika dilihat dari rumus yang digunakan dalam algoritme dekripsi adalah rumus kebalikan dari proses enkripsi.

\begin{tabular}{|l|c|c|c|}
\hline \multirow{2}{*}{ Citra Asli } & \multirow{2}{*}{ UACI (\%) } & \multicolumn{2}{c|}{ Waktu Proses (detik) } \\
\cline { 3 - 4 } & & enkrip & dekrip \\
\hline Lenna & 30,1256 & 2,699 & 2,746 \\
\hline Barbara & 30,4604 & 3,137 & 2,795 \\
\hline Pepper & 32,5137 & 2,974 & 2,856 \\
\hline Baboon & 30,1103 & 2,873 & 2,841 \\
\hline Saiboat & 32,4561 & 2,862 & 2,995 \\
\hline UGM & 33,1439 & 3,136 & 3,091 \\
\hline
\end{tabular}

Tabel 2. Hasil enkripsi terhadap beberapa Citra Uji.

\begin{tabular}{|l|c|c|c|c|c|c|}
\hline \multirow{2}{*}{ Citra Fraktal } & \multicolumn{2}{|c|}{ UACI Lenna } & \multicolumn{2}{c|}{ UACI Sailboat } & \multicolumn{2}{c|}{ UACI UGM } \\
\cline { 2 - 7 } & Multi & single & Multi & single & Multi & single \\
\hline Mandelbrot1 & 30,5599 & 30,3162 & 31,6867 & 31,7810 & 32,6850 & 32,5362 \\
\hline Mandelbrot2 & 30,4634 & 30,4424 & 32,2024 & 32,2434 & 33,3151 & 33,3373 \\
\hline Mandelbrot3 & 30,1256 & 30,4084 & 32,4562 & 32,1383 & 33,1439 & 33,9972 \\
\hline Mandelbrot4 & 30,4634 & 29,8663 & 32,2047 & 31,8096 & 33,2223 & 32,7809 \\
\hline Mandelbrot5 & 30,4820 & 30,2349 & 32,1998 & 32,1622 & 33,5927 & 33,1934 \\
\hline Rerata & $\mathbf{3 0 , 4 1 8 9}$ & $\mathbf{3 0 , 2 5 3 6}$ & $\mathbf{3 2 , 1 4 9 9}$ & $\mathbf{3 2 , 0 2 6 9}$ & $\mathbf{3 3 , 1 9 1 8}$ & $\mathbf{3 3 , 1 6 9}$ \\
\hline
\end{tabular}

Tabel 3. Hasil enkripsi menggunakan citra fraktal single dan multi.

\section{KESIMPULAN}

Dari penelitian yang dilakukan dapat ditarik beberapa kesimpulan sebagai berikut :

1. Telah berhasil disusun algoritme dan program untuk melakukan enkripsi dan dekripsi citra warna menggunakan citra fraktal Mandelbrot $\mathrm{z}^{2}-\mathrm{c}$.

2. Program yang dibuat dapat melakukan pemilihan citra fraktal Mandelbrot yang akan digunakan dalam enkripsi dan dekripsi serta dapat menyimpan data key yaitu koordinat batas-batas domainnya, yaitu berupa 4 bilangan real.

3. Citra hasil enkripsi dari 6 citra uji dianalisis dengan menentukan nilai NPCR dan UACI, dimana nilai NPCR semuanya $100 \%$ sedangkan rerata nilai UACI adalah $31,47 \%$. Waktu enkripsi reratanya adalah 2.95 detik dan waktu dekripsi reratanya 2,89 detik. Citra hasil dekripsi mempunyai RMSE $=0$ terhadap citra asli, hal ini menunjukkan bahwa citra hasil dekripsi sama persis dengan citra asli, sedangkan dari hasil nilai UACI dari beberapa data uji dan juga berdasarkan pengamatan secara visual didapat bahwa citra hasil enkripsi menggunakan multi fraktal sedikit lebih baik dibandingkan dengan single fraktal.

\section{DAFTAR PUSTAKA}

[1]. Abd-El-Hafiz S.K. dkk., 2014, “A fractal-based image encryption system”, IET Image Process., Vol. 8, Iss. 12, pp. 742-752.

[2]. Chopra A. dkk., 2015, “An Enhanced Modulo-based Image Encryption Using Chaotic and Fractal Keys”, 
978-1-4673-6911-4/15/\$31.00@2015 IEEE.

[3]. Gupta, N. dan Vijay, R., 2020, "Effect on Reconstruction of Images by Applying Fractal Based Lossy Compression Followed by Symmetrical Encryption Techniques", 11th ICCCNT 2020 July 1-3, 2020 IIT- Kharagpur.

[4]. Lan, R.Y.H. dan Wu, Q., 2018, “A Fractal Interpolation Based Image Encryption Scheme”, 978-1-53867437-6/18/\$31.00 @2018 IEEE.

[5]. Lock, A.J.J. dkk., 2010, “Compression-Encryption Based on Fractal Geometric”, 978-0-7695-4043-6/10 $\$ 26.00$ @ 2010 IEEE.

[6]. Sun Y. dkk., 2010, “An Image Encryption Algorithm Utilizing Mandelbrot Set”, 978-0-7695-4247-8/10 $\$ 26.00$ (C) 2010 IEEE.

[7]. Zhang, X. dkk., 2019, “A Chaos-Based Image Encryption Technique Utilizing Hilbert Curves and HFractals", 2169-3536 2019 IEEE.

\section{Biodata Penulis}

Drs. Janoe Hendarto M.Kom., memperoleh gelar Sarjana Matematika (Drs.), Program Studi Matematika FMIPA UGM, lulus tahun 1986. Tahun 1992 memperoleh gelar Magister Komputer (M.Kom) dari Program Studi Ilmu Komputer Program Pascasarjana UI. Saat ini sebagai Staf Pengajar program studi S1 Ilmu Komputer Departemen Ilmu Komputer dan Elektronika FMIPA Universitas Gadjah Mada. 